\title{
DIE OPLEIDING VAN BEDRYFSIELKUNDIGES AAN DIE POTCHEFSTROOMSE UNIVERSITEIT VIR CHRISTELIKE HOËR ONDERWYS
}

\author{
C.F. SCHOEMAN \\ DEPARTEMENT BEDRYFS- EN PERSONEELSIELKUNDE \\ POTCHEFSTROOMSE UNIVERSITEIT VIR CHRISTELIKE HOËR ONDERWYS
}

Die Bedryf- en Personeelsielkunde het tot 1968 onder die Departement Sielkunde geressorteer. Daarna het dit 'n selfstandige departement geword, eers in die Fakulteit Lettere en Wysbegeerte en vanaf 1976 in die Fakulteit Ekonomiese Wetenskappe.

Die personeel verbonde aan die departement het aanvanklik bestaan uit 'n Professor bygestaan deur ' $n$ Lektor. Sedertdien het die personeelgetalle gegroei tot die huidige getal van 7 bestaande uit 'n Professor, 2 Senior Lektore, 2 Lektore en 2 Junior Lektore. Drie lede van die personeel is geregistreer by die Beroepsraad as Bedryfsielkundiges en een as Kliniese Sielkundige.

Studentegetalle het in die periode 1970 tot 1977 soos volg vermeerder:

$\begin{array}{lcc} & 1970 & 1977 \\ \text { Eerste jaar } & 126 & 217 \\ \text { Tweede jaar } & 31 & 87 \\ \text { Derde jaar } & 46 & 94 \\ \text { Honneursgraad } & 6 & 21 \\ \text { Magistergraad } & 1 & 6 \\ \text { Doktorsgraad } & - & -\end{array}$

\section{Graadrigtings en Vakkombinasies}

Bedryf- en Personeelsielkunde kan vir die volgende graadrigtings geneem word: B.Comm., B.A., B.A.Komm., B.A. Bibl. En B.Sc.

Bedryf- en Personeelsielkunde kan saam met die volgende hoofvakke gekombineer word:

(i) Vir die B.Comm.-graad: Bedryfsekonomie, plus een van die volgende: Bedryfsosiologie, Rekeningkunde en Ekonomie.

(ii) Vir die B.A.-graad: 'n Groot verskeidenheid van vakke, o.a. Bybelkunde, Ekonomie, Geskiedenis, Bedryfsosiologie, Kommunikasiekunde ens.

(iii) Vir die B.Sc.-graad: Rekenaarwetenskap, Teorie van Statistiek en Wiskunde. 
Die vak Bedryf- en Personeelsielkunde word ook aangebied in die HBA- en MBAgrade asook vir elektrotegniese Ingenieurs en vir die Universiteitsdiploma in Handel (UDH).

\section{Kursusinhoud}

By die samestelling van die kursusinhoud is uitgegaan van die standpunt dat Bedryf- en Personeelsielkunde 'n spesialiseringsrigting in die Sielkunde is.

Kursus I: $\quad$ Vraestel 1: $\quad$ Inleiding tot die Sielkunde as wetenskap Inleiding tot kwantitatiewe metodes

Vraestel 2: $\quad$ Inleiding tot die Bedryfsielkunde Inleiding tot eksperimentele navorsing

Kursus II: Vraestel 1A: Psigopatologie w.o. begrippe normaliteit asook spanningsdisfunksies

Vraestel 1B: Sosiale Sielkunde w.o. groepdinamika, houdings ens.

Vraestel 2: Bedryf-en Personeelsielkunde w.o. die indiensnemingsfunksie, fisiese werktoestande, menseverhoudings en personeelprobleme.

Vraestel 3: Eksperimentele Bedryfsielkunde bestaande uit kwantitatiewe metodes, psigometrie, toetse en praktiese opleidingstegnieke.

Kursus III: Vraestel 1: Bedryf- en Personeelsielkunde bestaande uit werkstudie, posevaluering, verkoopsielkunde, ergonomika, werksmotivering, personeelontwikkeling en groepbespreking.

Vraestel 2A: Psigopatologie w.o. neuroses en psigoses, organiese breindisfunksies en verstandelike vertraging.

Vraestel 2B: Karakterologie asook bestuurs- en organisasie-ontwikkeling. Vraestel 3: $\quad$ Eksperimentele Bedryfsielkunde w.o. navorsingsmetodes, rolspel, statistiese metodes, psigometrie, praktiese onderhoudsvoering asook eksperimente i.v.m. werkstudie, posevaluering, reklame ens.

\section{Vakansiewerk}

Studente wat Bedryf- en Personeelsielkunde neem moet vir een maand gedurende hulle tweede en/of derde jaar in 'n bedryf praktiese werk doen. 'n Verslag moet ingehandig word. 


\section{Honneurs}

Vraestel 1: $\quad$ Sosiale Sielkunde w.o. die individu se skakeling in die sosiale omgewing, t-groepopleiding ens.

Vraestel 2: Personeelsielkunde w.o. die ruitekaart-teorie in die organisasie-ontwikkelingsbenadering asook resente teorieë oor werksmotivering, salaris en salarisadministrasie.

Vraestel 3: Capita Selecta w.o. doelwitbestuur, gespreksanalise, ergonomika asook probleme wat in verband staan met die ouer werker.

Vraestel 4: Bedryfsielkunde. Die totale personeelfunksie van bestuur asook Verbruikersielkunde.

Vraestel 5: Eksperimentele Bedryf- en Personeelsielkunde w.o. gevorderde statistiek soos bv. ko-variansieontleding en faktorontleding, nie-parametriese metodes, psigometrie en 'n aantal toetse.

\section{Magister}

Twee goedgekeurde vraestelle in die Bedryfsielkunde en 'n verhandeling. Tans word aan 'n gerigte Magister gewerk met die oog op 'n internskap en registrasie by die Mediese en Tandheelkundige Raad as Bedryfsielkundige.

\section{D.-graad}

Proefskrif gebaseer op navorsing in 'n bedryf/bedrywe.

\section{Toegepaste navorsing}

Aangesien Bedryfsielkunde 'n baie sterk praktiese inslag het, word volgehoue skakeling met die bedryf ' $n$ belangrike prioriteit. In hierdie verband is daar baie noue skakeling veral vanaf 1973 met die Koöperatiewe beweging gevind t.o.v. personeelfunksies. So is hulp verleen met keuring (6), opleiding van middel- en topbestuur in die beginsels van bestuur (10), doelwitbestuur en merietebepaling (2), posevaluering, organisasiestrukture en vergoedingstelsels (12) terwyl by 'n aantal Koöperasies aandag geskenk is aan die vestiging en uitbouing van die personeelfunksie van bestuur.

Waar stelsels van navorsingsituasies soos bv. die N.I.P.N. gebruik is (posevaluering), is terugvoering aan hulle gegee terwyl praktiese probleme wat by toepassing ondervind is asook wysigings wat aangebring is, met hulle bespreek is. 


\section{Beroepsmoontlikhede}

As gevolg van die toenemende bewuswording van die belangrikheid om die mens optimaal te benut, het die aanvraag vir personeeldeskundiges aansienlik toegeneem. Dit het meegebring dat bedryfsielkundiges se dienste in verskeie sektore benodig word, w.o. navorsingsinstansies, opvoedkundige inrigtings en in die praktiese sakewêreld. Ons beskou dus opleiding in hierdie toegepaste dissipline as van wesenlike belang in die uitbouing en stabilisering van ons landsekonomie en voorsien dat studente wat hul in hierdie rigting bekwaam, 'n waardevolle bydrae kan lewer.

Die opleiding is so ingestel dat die student met die nodige studie en ervaring kan registreer as bedryfsielkundige. 